\title{
DEFORMATION BEHAVIOR OF THE Mg-7Zn-3Cu-1Ce ALLOY DURING HOT COMPRESSION
}

\author{
ŠTUDIJ DEFORMACIJE MAGNEZIJEVE ZLITINE Mg-7Zn-3Cu-1Ce \\ MED VROČIM STISKANJEM
}

\author{
Yaobo Hu${ }^{1}$, Wanqiu Meng ${ }^{1}$, Tianxu Zheng ${ }^{1}$, Chao Zhang ${ }^{1}$, Qin Yang ${ }^{2}$, Zhentao Zhu ${ }^{2}$ \\ ${ }^{1}$ Chongqing University, College of Materials Science and Engineering, 400044 Chongqing, China \\ ${ }^{2}$ Chongqing Chang'an Global R\&D Center, Chang'an Automobile Co, Ltd, 400044 Chongqing, China \\ yaobohu@cqu.edu.cn \\ Prejem rokopisa - received: 2017-07-25; sprejem za objavo - accepted for publication: 2017-10-02
}

doi:10.17222/mit.2017.124

The flow stress behavior of the $\mathrm{Mg}-7 \mathrm{Zn}-3 \mathrm{Cu}-1 \mathrm{Ce}$ alloy was studied on a Gleeble-1500 thermal/mechanical simulation test machine under the maximum deformation degree of $50 \%$, at a strain rate of $0.01 \mathrm{~s}^{-1}$ to $10 \mathrm{~s}^{-1}$, and temperature of 573 to $673 \mathrm{~K}$. The hot deformation behavior of the tested alloy during the hot compression process was studied. The experimental results showed that the correlation of the flow stress, strain rate and temperature was obvious and the tested alloy was a strain-ratesensitive material. The deformation activation energy $(Q=191 \mathrm{~kJ} / \mathrm{mol})$ and the corresponding stress exponent $(n=5.68)$ were evaluated by linear regression analysis during the hot deformation process. And the flow stress constitutive equation of the $\mathrm{Mg}-7 \mathrm{Zn}-3 \mathrm{Cu}-1 \mathrm{Ce}$ alloy was built by introducing the Zener-Hollomon parameter. There was no recrystallization phenomenon in the microstructure of the tested alloy after hot-compression, and dynamic recovery is the main softening mechanism during the high-temperature deformation. The extruded alloy (extrusion at $673 \mathrm{~K}$ ) shows excellent mechanical properties both at room and at mid-high temperature.

Keywords: hot deformation, deformation activation energy, stress exponent, dynamic recovery

Avtorji članka so študirali napetost tečenja magnezijeve zlitine $\mathrm{Mg}-7 \mathrm{Zn}-3 \mathrm{Cu}-1 \mathrm{Ce}$ s pomočjo termomehanskega simulatorja Gleeble-1500 do maksimalne stopnje deformacije $50 \%$, pri hitrostih deformacije od $0,01 \mathrm{~s}^{-1}$ do $10 \mathrm{~s}^{-1}$ in $\mathrm{v}$ temperaturnem območju med $573 \mathrm{~K}$ in $673 \mathrm{~K}$. Studirali so potek deformacije preiskovane zlitine med vročim stiskanjem. Eksperimentalni rezultati kažejo, da je korelacija med napetostjo tečenja, hitrostjo deformacije in temperaturo očitna in da je preiskovani material zelo občutljiv na hitrost deformacije. Aktivacijska energija za deformacijo $(Q=191 \mathrm{~kJ} / \mathrm{mol})$ in odgovarjajoči napetostni eksponent $(n=5,68)$ sta bila ovrednotena s pomočjo linearne regresijske analize med procesom vroče deformacije. S pomočjo uvedbe Zener-Hollomonovega parametra so zgradili konstitutivno enačbo za napetost tečenja magnezijeve zlitine $\mathrm{Mg}-7 \mathrm{Zn}-3 \mathrm{Cu}-1 \mathrm{Ce}$. Ugotovili so da ni prišlo do rekristalizacije mikrostrukture preiskovane zlitine po vročem stiskanju in da je glavni mehanizem mehčanja med visoko temperaturno deformacijo dinamična poprava. Zlitina ekstrudirana pri $673 \mathrm{~K}$ ima odlične mehanske lastnosti tako pri sobni, kot srednje povišanih temperaturah.

Ključne besede: deformacija v vročem, aktivacijska energija za deformacijo, napetostni eksponent, dinamična poprava

\section{INTRODUCTION}

Magnesium alloys: with the advantages of high specific strength, high specific stiffness, good damping and electromagnetic shielding performance, show broad application prospects, and have become some of the ideal materials in automotive, aviation and other areas. ${ }^{1}$ The $\mathrm{Mg}-\mathrm{Zn}$ alloy is a typical kind of high-strength wrought magnesium alloy, adding $\mathrm{Cu}$ to the binary $\mathrm{Mg}-\mathrm{Zn}$ alloy will raise the solution temperature, so that more $\mathrm{Zn}$ and $\mathrm{Cu}$ elements can be soluted into the $\mathrm{Mg}$ matrix at higher solution temperature, this will enhance the solution strengthening as well as the aging strengthening. ${ }^{2-3}$ ZC63 and ZC62 are two typical Mg-Zn-Cu alloys, with the mechanical performance of as-cast ZC63 after aging being better than the AZ91 alloy. ${ }^{4}$ The toughness of the as-cast ZC62 alloy at $423 \mathrm{~K}$ is better than that of the AS21 alloy. Moreover, the casting products of ZC62 have been successfully applied in the field, including car engine, thruster and other situations those need to resist high temperature (423 K).
The poor ductility of magnesium alloys has been attributed to highly anisotropic dislocation slip behavior. Magnesium alloys have a hexagonal close-packed (hcp) crystal structure, which makes it more difficult to conduct plastic deformation at room temperature. However, some non-basal slip planes begin to be activated and the number of slip systems increases at elevated temperature, thus the plasticity and deformation performance are improved. ${ }^{5-10}$ For example, the research of A. Chapuis and J. H. Driver ${ }^{11}$ have shown that tensile twinning and basal slip are only slightly temperature-dependent, but the critical resolved shear stresses (CRSSs) value of other systems (compressive twinning, prismatic and pyramidal II $(c+a)$ slip) decrease substantially with increasing temperature. Therefore, it is of great importance to study the plastic deformation behavior and processing parameters of magnesium alloys at elevated temperature. In recent years, the studies of the hot compressive deformation behaviors of magnesium alloys mainly concentrated on the Mg-Al-Zn, Mg-Zn-Zr and $\mathrm{Mg}-\mathrm{Gd}$ 
series. ${ }^{7-10,12-13}$ The evolution of the microstructure and texture of the AZ90 alloy during hot compression was studied by H. Ding et al. ${ }^{12}$ and X. L. Hou et al. ${ }^{14}$ investigated the microstructure evolution of $\mathrm{Mg}-8 \mathrm{Gd}-2 \mathrm{Y}-$ $1 \mathrm{Nd}-0.3 \mathrm{Zn}-0.6 \mathrm{Zr}$ alloy subjected to hot compression at $623 \mathrm{~K}$ and strain rate of $0.5 \mathrm{~s}^{-1}$. However, the reports about hot compressive deformation behaviors on $\mathrm{Mg}$ $\mathrm{Zn}-\mathrm{Cu}$ series magnesium alloys are limited. T. Zhang et al. ${ }^{15}$ added a certain amount of Sn to ZC63 alloy, the results showed that the addition of $\mathrm{Sn}$ significantly improved the strength of the ZC63 magnesium alloy due to grain refinement strengthening, solid solution strengthening and precipitation strengthening. Adding a rare-earth element could have a beneficial effect on $\mathrm{Mg}$ alloys. ${ }^{13-14,16-23}$ The creep resistance of the ZC63 magnesium alloy increased with adding $\mathrm{La}^{3}{ }^{3}$ and the Ce-rich RE-containing alloy exhibited a better creep resistance than the La-rich RE-containing alloy, ${ }^{19}$ mainly due to the formation of a grain boundary network of thermally stable phases, which can effectively inhibit grain-boundary migration and sliding during the creep process.

In this study, we added the rare-earth element $\mathrm{Ce}$ to the basic $\mathrm{Mg}-7 \mathrm{Zn}-3 \mathrm{Cu}$ alloy. Then the hot compression deformation behavior and the microstructure of the alloy under different deformation rates at high temperature were studied. The study of the relations of some relevant parameters, such as stress exponent $n$, deformation activation energy $Q$ and temperature $T$ are also included. The research results not only provide guides to the hot working processes of the alloy, but also offer some necessary experimental data and references to the numerical simulation research of the $\mathrm{Mg}-\mathrm{Zn}-\mathrm{Cu}$ alloy processing.

\section{EXPERIMENTAL PART}

The $\mathrm{Mg}-7 \mathrm{Zn}-3 \mathrm{Cu}-1 \mathrm{Ce}$ (mass fraction) magnesium alloy was prepared by die casting using high-purity magnesium (>99.98 w/\%) and zinc (>99.97 w/\%), as well as Mg-(30w/\%)Cu, Mg- $(20 w / \%) \mathrm{Ce}$ and $\mathrm{Mg}-(4$ $w / \%) \mathrm{Mn}$ magnesium-based master alloys. The melt was protected with $99 \%$ of volume fractions of $\mathrm{CO}_{2}$ and $1 \%$ of volume fractions of $\mathrm{SF}_{6}$ as protective gas during the process of melting. The actual composition of the prepared magnesium alloy is shown in Table 1. After homogenizing annealing (heated at $673 \mathrm{~K}$ for $24 \mathrm{~h}$ ), experimental samples $(\phi 10 \mathrm{~mm} \times 12 \mathrm{~mm})$ were prepared for the hot compression experiment. The samples were gummed with graphitic lubricant on both sides to reduce the impact of friction, then hot compression experiments were conducted using a Gleeble-1500 thermal/mechanical simulation machine. The heating rate was $276 \mathrm{~K} / \mathrm{s}$, then held for $3 \mathrm{~min}$, and the temperature for deformation was $(573,623$ and 673$) \mathrm{K}$ at different deformation rate of $\left(0.01,0.1,1\right.$ and 10) $\mathrm{s}^{-1}$, respectively. Meanwhile, the expected maximum deformation value was $50 \%$. The correlative experimental parameter referenced some previous studies. ${ }^{24-25}$ After the hot deformation, the samples were quenched immediately with cold water.

In this study, the morphology of as-cast, homogenizing annealing and hot compression were studied by optical microscopy, and scanning electron microscopy (TESCAN VEGA 3 LMH SEM, only for as-cast). The etching solution was a mixture of $90 \mathrm{~mL}$ alcohol, $5 \mathrm{~mL}$ acetic acid, $5 \mathrm{~g}$ picric acid and $10 \mathrm{~mL}$ distilled water. In order to get the phase composition of the alloy, phase analyses of the cast sample $(10 \mathrm{~mm} \times 10 \mathrm{~mm} \times 10 \mathrm{~mm})$ was analysed by X-ray diffraction (XRD Rigaku D/MAX-2500PC X) with $\mathrm{Cu}-K_{\alpha}$, the range of scan angle was between $10^{\circ}$ and $90^{\circ}$, the scan speed was $4^{\circ} / \mathrm{min}$ and we used Jade 5.0 software for the data analysis.

The extrusion temperature for the alloy was $573 \mathrm{~K}$, the extrusion ratio was about 81 and the extrusion rate was $2.0 \times 10^{-3} / \mathrm{s}$. The samples used for tensile tests at ambient and high temperature were prepared based on GB/T228-2002 and GB/T4338-1995, respectively. The tensile test was conducted by a CMT-5105 electronic universal testing machine at the rate of $2 \mathrm{~mm} / \mathrm{min}$, with the temperature of $(273,323,348$ and 373$) \mathrm{K}$.

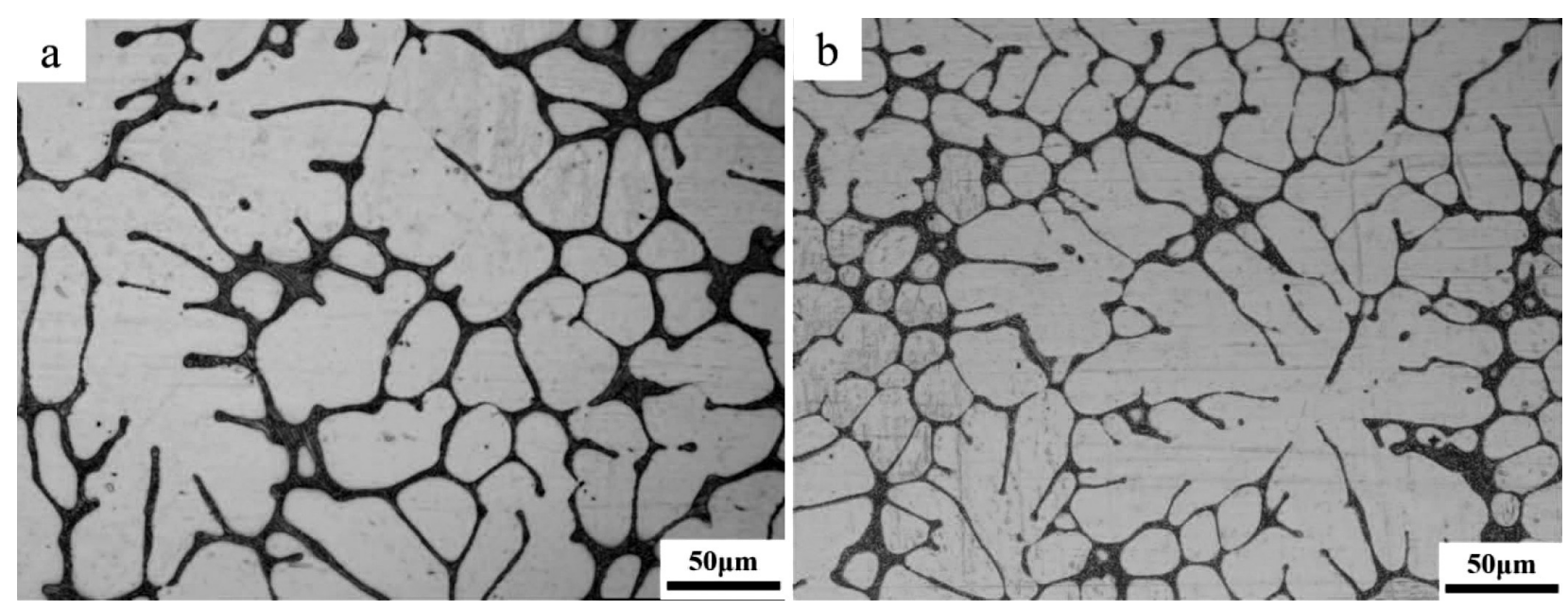

Figure 1: Metallographic images of $\mathrm{Mg}-7 \mathrm{Zn}-3 \mathrm{Cu}-1 \mathrm{Ce}$ alloys: a) as-cast, b) homogenized 
Table 1: Actual composition of the alloy, in mass fractions $(w / \%)$

\begin{tabular}{|c|c|c|c|c|}
\hline $\mathrm{Mg}$ & $\mathrm{Zn}$ & $\mathrm{Cu}$ & $\mathrm{Ce}$ & $\mathrm{Mn}$ \\
\hline Bal. & 7.2 & 3.4 & 0.9 & 0.3 \\
\hline
\end{tabular}

\section{RESULTS}

\subsection{As-cast structure of the alloy}

Figure 1 shows the microstructure of the $\mathrm{Mg}-7 \mathrm{Zn}-3 \mathrm{Cu}-1 \mathrm{Ce}$ alloy. It is clear that the as-cast structure shows typical dendrite shapes, consisting of $\alpha-\mathrm{Mg}$ matrix and net-like black compounds distributed along the interdendritic. Dendritic segregation is obvious; there are many compounds between the dendrites. According to the $\mathrm{Mg}-\mathrm{Zn}$ binary eutectic phase diagram, the content of $\mathrm{Zn}$ in this alloy exceeds the maximum solid solubility of $\mathrm{Zn}$ in $\mathrm{Mg}$ matrix (6.2\%), $\alpha-\mathrm{Mg}$ and $\mathrm{Mg}-\mathrm{Zn}$ binary phase generate directly from the liquid phase at about $621 \mathrm{~K}$. The addition of $\mathrm{Cu}$ makes the original $\mathrm{Mg}-\mathrm{Zn}$ binary phase change into eutectic $\mathrm{Mg}$ ( $\mathrm{Zn}, \mathrm{Cu}$ ) compound. It is clear from the XRD spectrum (Figure 2), there are mainly diffraction peaks of $\alpha-\mathrm{Mg}$,

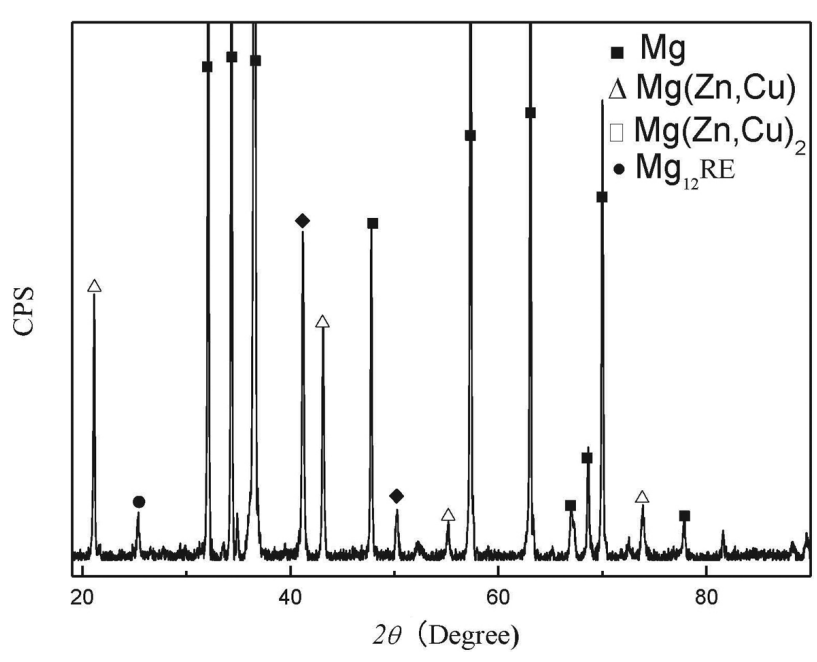

Figure 2: X-ray diffraction pattern of $\mathrm{Mg}-7 \mathrm{Zn}-3 \mathrm{Cu}-1 \mathrm{Ce}$ as-cast alloy

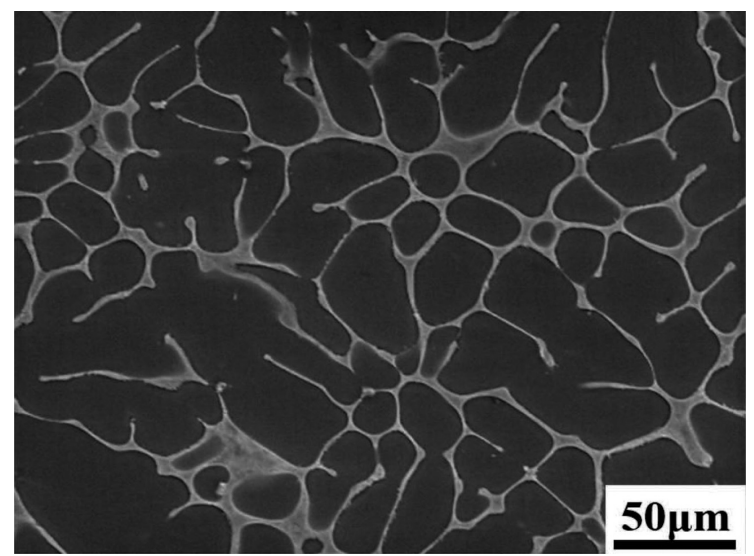

Figure 3: SEM micrograph of as-cast $\mathrm{Mg}-7 \mathrm{Zn}-3 \mathrm{Cu}-1 \mathrm{Ce}$
$\mathrm{Mg}(\mathrm{Zn}, \mathrm{Cu})$ and $\mathrm{Mg}(\mathrm{Zn}, \mathrm{Cu})_{2}$ phase. But there is an obvious diffraction peak at $2 \theta=25^{\circ}$, which is attributed to the second phase containing $\mathrm{Ce}$, and it was identified as thermally stable $\mathrm{Mg}_{12} \mathrm{RE}$ and $\mathrm{MgRE}$ compounds. ${ }^{3,24}$ As presented in Figure 3, it is obvious that a grainboundary interphase network is formed because of the Ce-rich RE addition. It was reported that the addition of Ce can reduce the solid solubility of other elements in the $\mathrm{Mg}$ matrix and increases the volume fraction of secondary phase. ${ }^{19}$ After homogenization treatment, only a small amount of compounds dissolve into the matrix, indicating that the inter-dendritic compounds have good thermal stability at elevated temperature. ${ }^{3,15}$

\subsection{True stress-strain curves}

The true stress-strain $(\sigma-\varepsilon)$ curves of Mg-7Zn$3 \mathrm{Cu}-\mathrm{Ce}$ alloy at different temperature are shown in Figure 4. According to the curves, the entire compression process can be divided into four stages, ${ }^{26}$ workhardening stage, stable stage, softening stage and steady stage. This is mainly a composite effect of work hardening and thermally activated softening. ${ }^{26}$ In the initial stage of the compression, elastic and plastic deformation occur, the true stress curve s linearly. This is primarily caused by a second-order pyramidal slip system $(c+a)$ dislocation motion. The strain increases as the compression continues, but dynamic recovery (DRV) or dynamic recrystallization (DRX) occurs, which soften the alloy, so the stress rises slowly to a maximum and then goes down. The stress and strain appear steady flow characteristics when the softening of DRV or DRX and work hardening get to balance in a certain strain value (such as the strain increased to around 0.2 with $573 \mathrm{~K}$ and $(0.01,0.1,1,10) \mathrm{s}^{-1}$; to $0.05 \mathrm{~s}^{-1}$ with $623 \mathrm{~K}$ and $0.01 \mathrm{~s}^{-1}$, to $0.25 \mathrm{~s}^{-1}$ with $623 \mathrm{~K}$ and $0.1 \mathrm{~s}^{-1}$, to $0.3 \mathrm{~s}^{-1}$ with $623 \mathrm{~K}$ and $1 \mathrm{~s}^{-1}$, to $0.15 \mathrm{~s}^{-1}$ with $623 \mathrm{~K}$ and $10 \mathrm{~s}^{-1}$; to $0.03 \mathrm{~s}^{-1}$ with $673 \mathrm{~K}$ and $0.01 \mathrm{~s}^{-1}$, to $0.05 \mathrm{~s}^{-1}$ with $673 \mathrm{~K}$ and $0.1 \mathrm{~s}^{-1}$, to $0.25 \mathrm{~s}^{-1}$ with $673 \mathrm{~K}$ and $(1,10) \mathrm{s}^{-1}$ ), while the flow stress is nearly unchanged latterly. Comparing the true stress-strain $(\sigma-\varepsilon)$ curves at different temperatures, under the same strain rate, the strain value of the alloy reaches the stress peak decreases as the temperature increases. At the same time, the flow stress decreases as the temperature increases, indicating DRV and DRX could happen more easily at elevated temperature and the softening degree increases. ${ }^{27-28}$ On the other hand, with the temperature increasing, the thermal activation energy increases, the kinetic energy of the atomic activity increases, the interatomic interaction force decreases, the diffusion speed of various point defects increases, the dislocation movement resistance decreases, and the deformation is more favorable. At the same temperature, the true stress of material increases with the increasing of strain rate, since per unit time of plastic deformation decreases and the number of dislocation increases dramatically with the increase of strain rate. The response time for DRV and DRX softening 

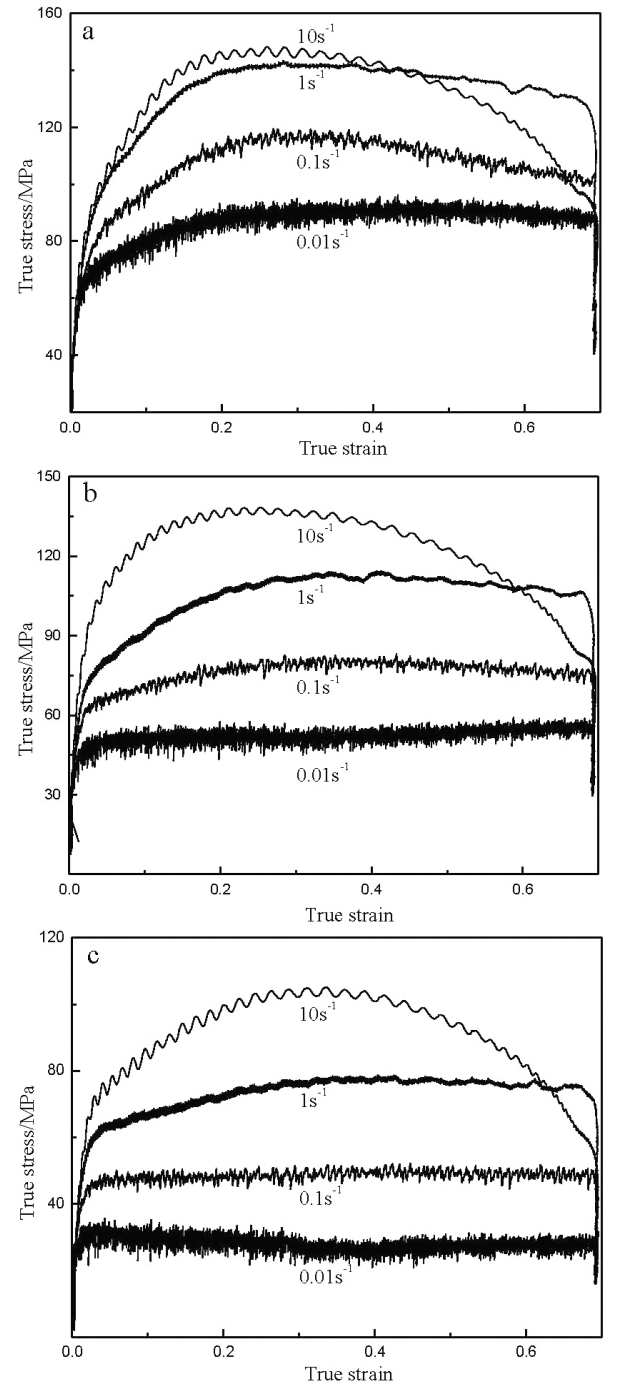

Figure 4: True stress-strain curves of $\mathrm{Mg}-7 \mathrm{Zn}-3 \mathrm{Cu}-1 \mathrm{Ce}$ alloy at different temperature: a) $573 \mathrm{~K}$, b) $623 \mathrm{~K}$, c) $673 \mathrm{~K}$

decreases simultaneously, and there is not enough time for plastic deformation, the critical resolved shear stress of the alloy increases, hence, leading to the flow stress increase. ${ }^{10,29-30}$

No prominent steady-state flow phenomenon could be seen after reaching the peak stress at the strain rate $10 \mathrm{~s}^{-1}$. In the late stage of compression, the true stress decreases rapidly. At a larger strain rate, analysis suggests that the speed of dislocation multiplication accelerated then enhances the density of dislocation; therefore the stress of the alloy increases with the increase of the strain. The stress falls down slowly when the strain gets to a certain value (such as the strain increased to around $0.4 \mathrm{~s}^{-1}$ with $573 \mathrm{~K}$ and $(0.1,10) \mathrm{s}^{-1}$, to $0.45 \mathrm{~s}^{-1}$ with $573 \mathrm{~K}$ and $1 \mathrm{~s}^{-1}$; to $0.55 \mathrm{~s}^{-1}$ with $623 \mathrm{~K}$ and $1 \mathrm{~s}^{-1}$, to $0.36 \mathrm{~s}^{-1}$ with $623 \mathrm{~K}$ and $10 \mathrm{~s}^{-1}$; to $0.42 \mathrm{~s}^{-1}$ with $673 \mathrm{~K}$ and $10 \mathrm{~s}^{-1}$ ), and the strain strengthening offsets the effect of DRV or DRX by softening. This is why DRV and DRX play an important role during hot deformation of magnesium alloys. ${ }^{31}$ However, the flow stress falls down quickly when the strain's cumulant exceeds 0.6. At this point, the strain rate is high enough to crush or reorganize the microstructure of the material, which makes the flow stress fall down sharply. There are many primary interdendritic compounds in as-cast structures. Those could be elongated due to the deformation of the matrix during the compression process. It is noteworthy that the primary interdendritic compounds are crushed when the compression reaches a certain degree and a few dot-like second phase distribute within the matrix, while secondary dendrites connects each other (Figure 10).

\subsection{Establishment of the constitutive equation}

According to the analysis of the true stress-strain curve, there are obvious interactions between the flow stress, temperature and strain rate. It can be explained by the terms of DRX and dislocation generation or motion mechanism in polycrystalline metals. ${ }^{26}$ Understanding the mathematical relationship between them, we can master the rule how flow stress changes during high-temperature plastic deformation.

Heat deformation is a thermal activation process. Its main feature behaves as the strain rate under the control of heat activation and obeys the Arrhenius rule: ${ }^{1}$

$$
\dot{\varepsilon}=\dot{\varepsilon}_{0} \exp \left(-\frac{Q}{R T}\right)
$$

where $Q$ is the deformation activation energy, $R(8.31$ $\mathrm{J} /(\mathrm{mol} \cdot \mathrm{K}))$ is the molar gas constant, $T$ is the deformation temperature $(\mathrm{K}), \dot{\varepsilon}$ is the strain rate $\left(\mathrm{s}^{-1}\right)$. During the actual heat deformation, flow stress is extremely sensitive to the applied stress, strain rate and temperature. ${ }^{10}$

Steady flow stress $\sigma$ and strain rate $\dot{\varepsilon}$ have the relation of exponent function under a low stress level:

$$
\dot{\varepsilon}=A_{1} \sigma^{n_{1}}
$$

where $A_{1}$ and $n_{1}$ are temperature-independent constants.

Steady flow stress $\sigma$ and strain rate $\dot{\varepsilon}$ have the relation of power function under a high stress level:

$$
\dot{\varepsilon}=A_{2} \exp (\beta \sigma)
$$

where $A_{2}$ and $\beta$ are temperature-independent constants.

After many researches on hot working data, Sellars and Tegart proposed an Arrhenius equation containing activation energy $Q$ and temperature $T:{ }^{30,33}$

$$
\dot{\varepsilon}=A[\sinh (\alpha \sigma)]^{n} \exp \left(-\frac{Q}{R T}\right)
$$

where $\alpha$ is a constant of stress level, $\alpha=\beta / n_{1}, n$ is stress exponent, $Q$ is deformation activation energy, $R$ $(8.31 \mathrm{~J} /(\mathrm{mol} \cdot \mathrm{K}))$ is molar gas constant, $T$ is absolute temperature $(\mathrm{K})$.

To obtain the value of $\alpha$, we must first have the values of $n_{1}$ and $\beta$. Take the logarithm on both sides of Equations (2) and (3), respectively: 


$$
\begin{gathered}
\ln \dot{\varepsilon}=\ln A_{1}+n_{1} \ln \sigma \\
\ln \dot{\varepsilon}=\ln A_{2}+\beta \sigma
\end{gathered}
$$

The curves of $\ln \dot{\varepsilon}-\ln \sigma$ and $\ln \dot{\varepsilon}-\sigma$ (Figure 5) could be obtained by performing linear regression using the least-squares method. It is easy to figure out the value of the slope $\left(n_{1}\right)$ of fitting line under low stress level at the temperature $623 \mathrm{~K}$ and $673 \mathrm{~K}\left(n_{1}=7.09\right)$. While the $\beta=0.109$ (the slope of fitting line under high stress level at the temperature $573 \mathrm{~K}$ and $623 \mathrm{~K}$ ), so we can calculate the value $\alpha=0.0154 \mathrm{~mm}^{2} / \mathrm{N}$.

Take the logarithm on both sides of Equation (4), as follows:

$$
\ln \dot{\varepsilon}+Q / R T=\ln A+n \ln [\sinh (\alpha \sigma)]
$$

Partial Equation (7), we can get the expression of $n$ and $Q$ :

$$
\begin{gathered}
n=\left.\frac{\partial \ln \dot{\varepsilon}}{\partial \ln [\sinh (\alpha \sigma)]}\right|_{T} \\
Q=R \frac{\partial \ln \dot{\varepsilon}}{\partial \ln [\sinh (\alpha \sigma)]}\left|\frac{\partial \ln [\sinh (\alpha \sigma)]}{\partial(1 / T)}\right|_{\dot{\varepsilon}}=R n b
\end{gathered}
$$
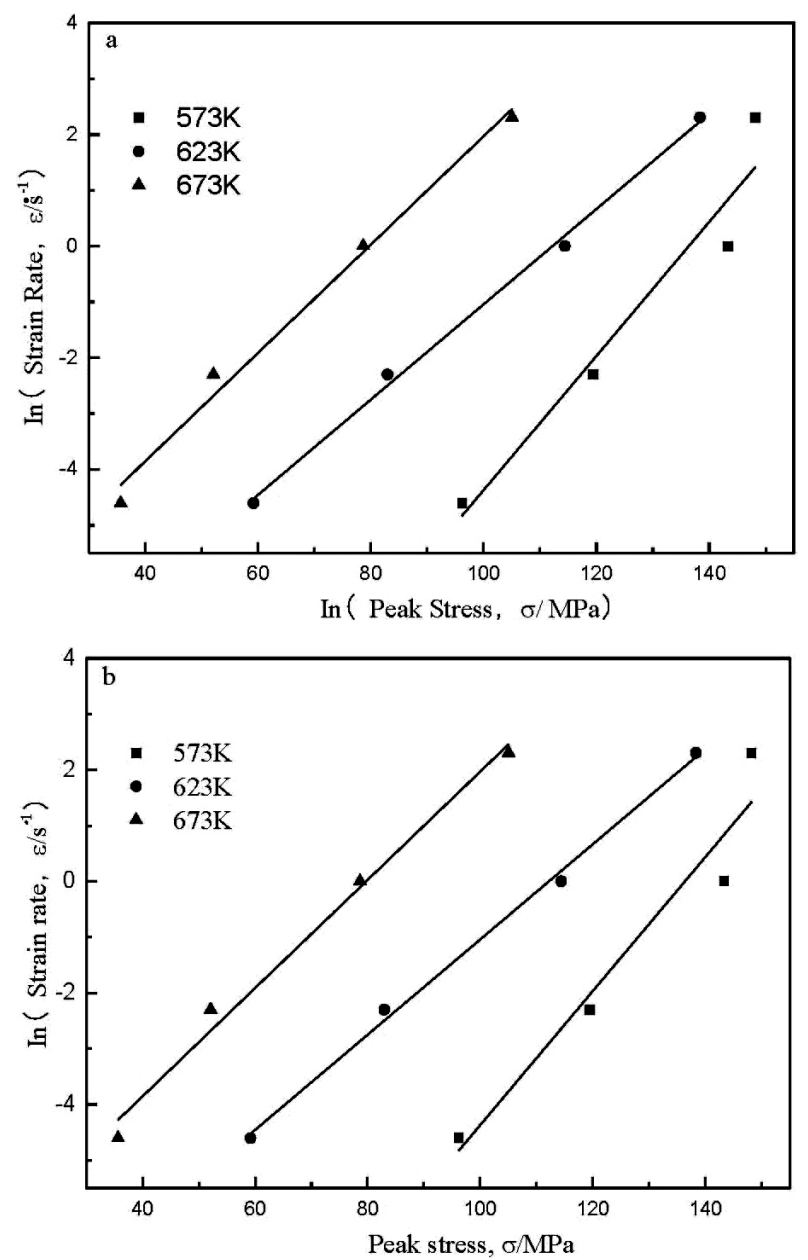

Figure 5: Relationship between strain rate and peak stress of $\mathrm{Mg}-7 \mathrm{Zn}-3 \mathrm{Cu}-1 \mathrm{Ce}$ alloy: a) $\ln \dot{\varepsilon}-\ln \sigma$, b) $\ln \dot{\varepsilon}-\sigma$

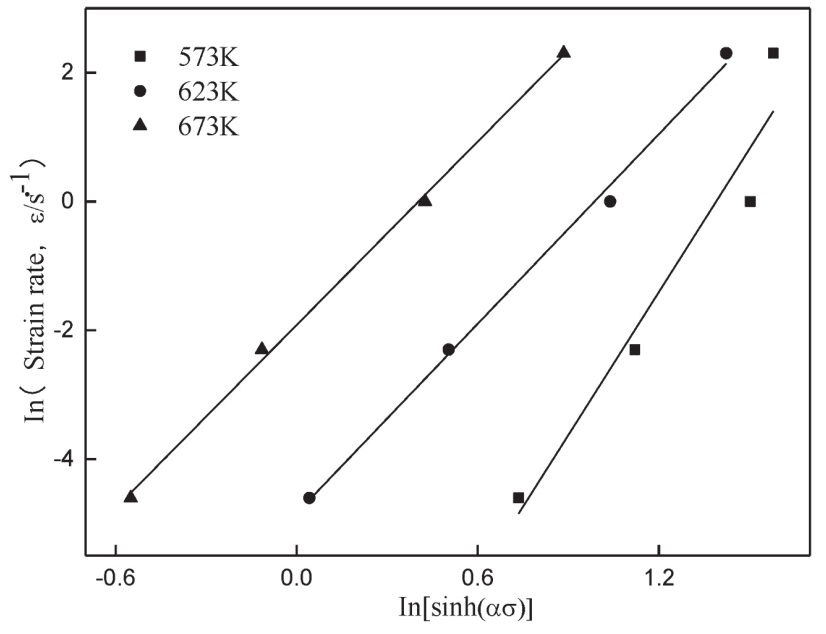

Figure 6: Relationship between strain rate and flow stress for Mg-7Zn-3Cu-1Ce alloy

According to Equation (8), we can get the stress exponent $n$ (Figure 6) by plotting and fitting the data of $\ln \dot{\varepsilon}$ and $\ln [\sinh (\alpha \sigma)]$, so the average of $n$ is 5.68 . According to Equation (9) similarly, Figure 7 is the curve of $\ln [\sinh (\alpha \sigma)]-T^{-1}$ and $b=4.04$. By calculation we can get the activation energy $\left(Q=1.91 \times 10^{2} \mathrm{~kJ} / \mathrm{mol}\right)$ of $\mathrm{Mg}-7 \mathrm{Zn}-3 \mathrm{Cu}-1 \mathrm{Ce}$.

Zener and Hollomon derived and proved the relationship between the strain rate and temperature could be described by the $Z$ parameter:

$$
Z=\dot{\varepsilon} \exp \left(\frac{Q}{R T}\right)=A[\sinh (\alpha \sigma)]^{n}
$$

Plug the value of $Q$ into the above Equation (10), and the expression of $Z$ is as follows:

$$
Z=\dot{\varepsilon} \exp \left(1.91 \times 10^{2} / R T\right)
$$

Take logarithm on both sides of equation (10) and we get $\ln Z=\ln A+n \ln [\sin (\alpha \sigma)]$. Figure 8 shows the relationship between $\mathrm{Z}$ and flow stress of experimental

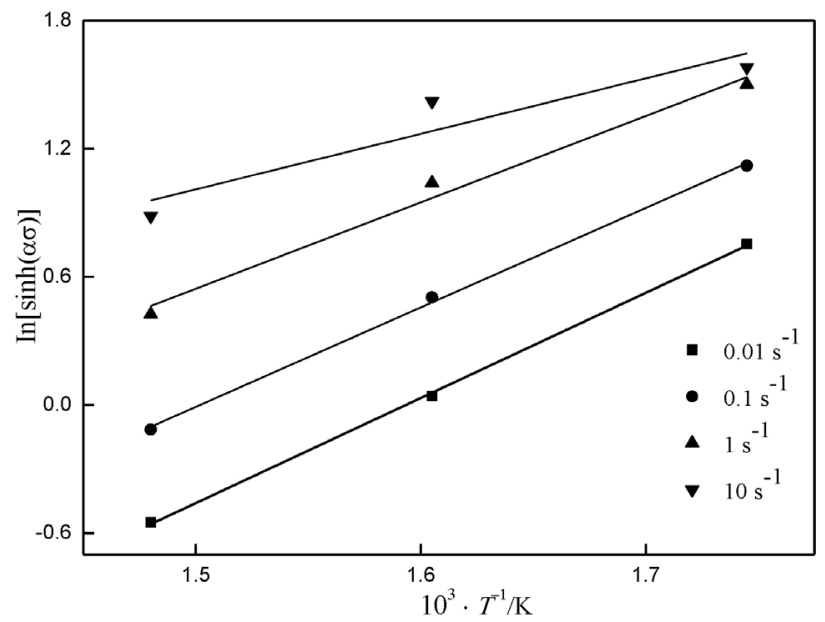

Figure 7: Relationship between flow stress and temperature of $\mathrm{Mg}-7 \mathrm{Zn}-3 \mathrm{Cu}-1 \mathrm{Ce}$ 


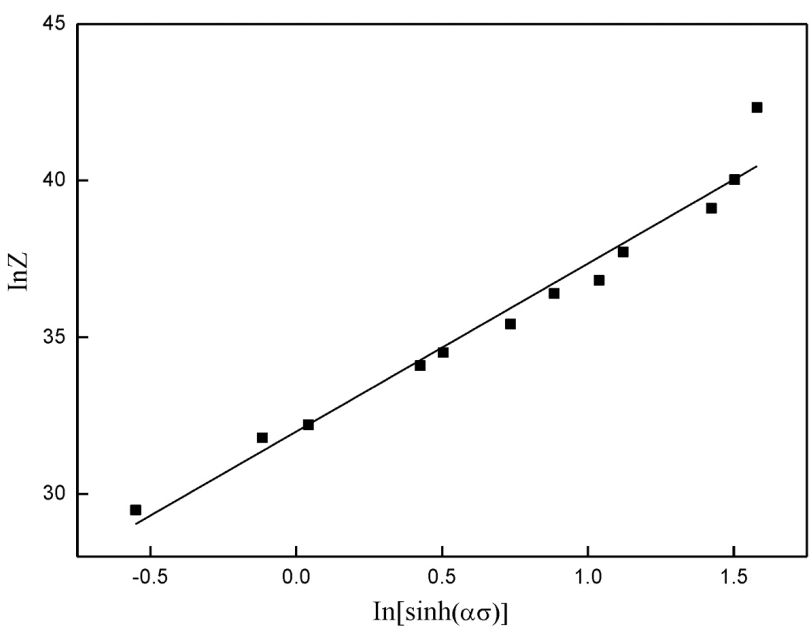

Figure 8: The relationship between $\mathrm{Z}$ and flow stress of experimental alloy

alloy and the correlation coefficient is 0.962 . It can be seen that high temperature compression deformation behaviour can be described using hyperbolic sine function, and $A=7.82 \times 10^{13} \mathrm{~s}^{-1}$.

According to the definition of inverse function of hyperbolic sine function, we obtain the relation between $\sigma$ and $\mathrm{Z}$ from Equation (10):

$$
\sigma=\frac{1}{\alpha}\left\{\left(\frac{Z}{A}\right)^{\frac{1}{n}}+\left[\left(\frac{Z}{A}\right)^{\frac{2}{n}}+1\right]^{T^{\frac{1}{n}}}\right\}
$$

Plug the value of $\alpha, n$ and $A$ into the above Equation (11), then we obtain the steady-state flow stress constitutive equation for thermal deformation of the experimental alloy.

Figure 9 shows the comparison between predicted value and measured value, and the slope of the fitting curve is 0.996. indicating the constitution equation has high accuracy.

\subsection{The microstructure evolution of $\mathrm{Mg}-7 \mathrm{Zn}-3 \mathrm{Cu}-1 \mathrm{Ce}$ during hot simulation}

Figure 10 provides the OM images perpendicular to the compression direction of the studied alloy after hot compression between $573 \mathrm{~K}$ and $673 \mathrm{~K}$ at a strain rate of $(0.01,0.1,1$ and 10$) \mathrm{s}^{-1}$. It is obvious that dendritic structures are significantly elongated because the softening of the matrix. When the temperature range is between $573 \mathrm{~K}$ and $623 \mathrm{~K}$, the microstructure is inhomogeneous and only part of the dendrite squeezed together as the matrix softening, forming a thin layer deformation zone. The deformation of the structure is relatively uniform at elevated temperature and almost all the dendrites participate in the coordinated deformation, and inter-dendritic eutectic structure becomes coarse, while slender macroscopic deformation zone reduces. Generally, hot deformation is the contradiction process of work hardening,

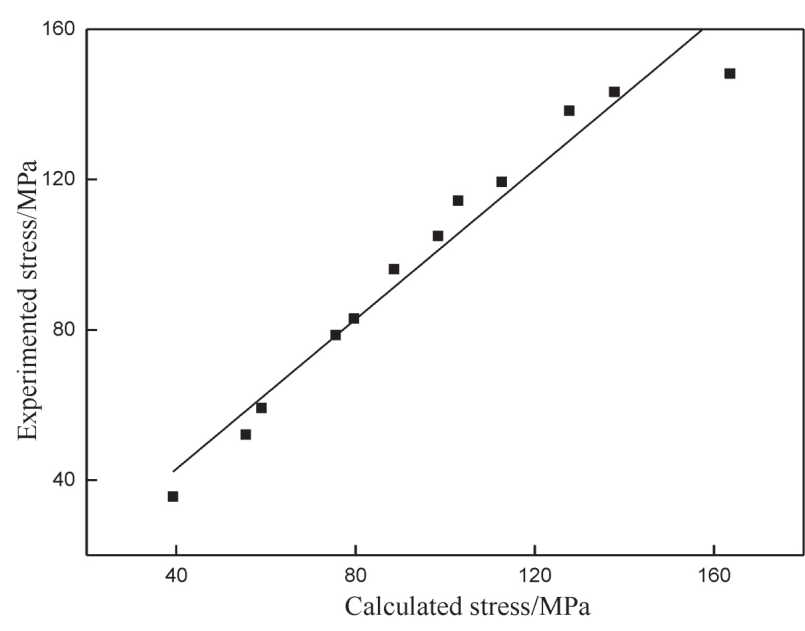

Figure 9: Comparison between predicted value and measured value

DRV and DRX. Nevertheless, recrystallization or twins appear in the microstructure at high temperature in the previous studies. ${ }^{9-10}$ However, the DRX does not appear in the microstructure at low strain rates between the deformation temperatures $573 \mathrm{~K}$ and $673 \mathrm{~K}$. This indicates that DRV is the main softening mechanism in the early stage of hot deformation. ${ }^{30}$ The opposite sign dislocations on the same slip plane attract each other, come together then disappear under the effect of thermal activation energy. While the opposite sign dislocations on the different slip plane disappear by vacancy condensation or vacancy escape, thus the density of dislocation decreases. The DRV mechanism turns into polygonization because the change of dislocation density with deformation temperature increases. During the process of recovery, dislocation moves, rearranges and ranges along the direction perpendicular to the slip plane, forming dislocation wall and sub-boundary or subgrain. ${ }^{23}$ This kind of sub-boundary cannot move easily that would not become the recrystallization core. Simultaneously, dislocation's polygonization occurs to release the stored energy. These can reduce the driver for subsequent recrystallization process. These eutectic structures are good thermal stability that could stabilize the sub-grain, preventing the grain boundary move effectively and slow down the process of DRX. S. W. Xu et al. ${ }^{25}$ studied the dynamic microstructure changes in AZ91 alloy during hot compression, showing the $\mathrm{Mg}_{17} \mathrm{Al}_{12}$ precipitates has an importance pinning effect for grain boundary and was greatly influenced by compression temperature. This suggests that the solute atoms or precipitates could influence the dynamic recrystallization. Consequently, the DRX temperature is increased.

\subsection{Mechanical properties of as-extruded Mg-7Zn- $3 \mathrm{Cu}-1 \mathrm{Ce}$}

According to the analysis above, there is obvious work hardening in the early stage of the deformation at 


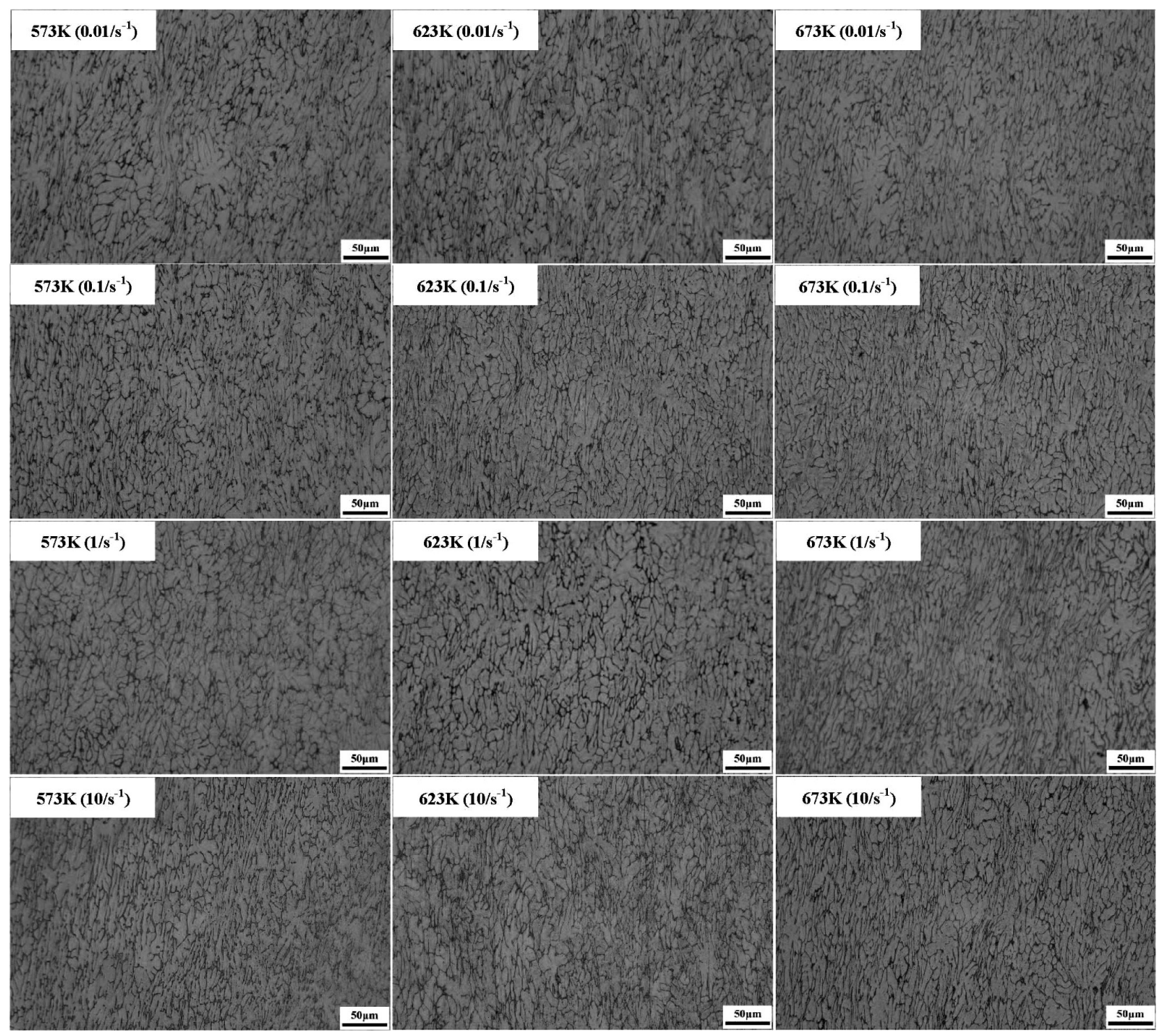

Figure 10: The effect of temperature on hot-compression microstructure of $\mathrm{Mg}-7 \mathrm{Zn}-3 \mathrm{Cu}-1 \mathrm{Ce}$ alloy between $573 \mathrm{~K}$ and $673 \mathrm{~K}$ at strain rate of $(0.01,0.1,1$ and 10$) \mathrm{s}^{-1}$

the temperature between $573 \mathrm{~K}$ and $623 \mathrm{~K}$. There is a steady flow phenomenon in the early stage of the deformation when the deformation is conducted at the temperature of $673 \mathrm{~K}$. And the deformed structure is most homogeneous at $673 \mathrm{~K}$. This indicates that dynamic recovery is the main softening mechanism at high temperature, which is favorable for the shaping of the alloy. In the present study, a higher temperature is generally utilized because a high deformation rate occurs during the extrusion process. ${ }^{12,24,32-34}$ Therefore, the

Table 2: Mechanical properties of $\mathrm{Mg}-7 \mathrm{Zn}-3 \mathrm{Cu}-1 \mathrm{Ce}$ alloy at room and elevated temperature.

\begin{tabular}{|c|c|c|c|}
\hline Temperature & $\sigma_{\mathrm{b}} / \mathrm{MPa}$ & $\sigma_{0.2} / \mathrm{MPa}$ & $\varepsilon / \%$ \\
\hline $273 \mathrm{~K}$ & 310 & 270 & 12.3 \\
\hline $423 \mathrm{~K}$ & 202 & 185 & 28.5 \\
\hline $448 \mathrm{~K}$ & 170 & 152 & 30.5 \\
\hline $473 \mathrm{~K}$ & 146 & 137 & 37.5 \\
\hline
\end{tabular}

extrusion temperature can be determined to be $673 \mathrm{~K}$ in this study. The mechanical properties of as-extruded alloys at room and elevated temperature are summarized in Table 2.

After extrusion, the tensile strength of the alloy at room temperature reaches $310 \mathrm{MPa}$, and the elongation rate reaches $12.3 \%$. At the temperature $423 \mathrm{~K}$, the tensile strength remains above $200 \mathrm{MPa}$, and shows good high temperature plasticity, elongation is nearly $30 \%$. The strength reduces as the temperature rises, but plasticity increases obviously. Interestingly, there is no obvious deterioration turning point of the strength as the tensile temperature rises. Above all, the $\mathrm{Mg}-7 \mathrm{Zn}-$ $3 \mathrm{Cu}-1 \mathrm{Ce}$ magnesium alloy shows not only excellent mechanical properties at room temperature, also good mechanical properties in the moderate and elevated temperature. It has great application potential as a heat- 
resistant magnesium alloy with its excellent elevated temperature performances and low cost.

\section{CONCLUSIONS}

1) The true stress level increases as the strain rate increases at same deformation temperature, indicating that alloy is a strain-rate sensitive material.

2) Under the condition of the same strain rate, there is no obvious dynamic recrystallization phenomenon during the process of hot compression, although the true stress level decreases as the temperature rises. In addition, the dynamic recovery is the main influencing factor on the softening of the alloy.

3) By analysing the flow stress, we calculated some basic material constants during high temperature deformation, stress exponent $n=5.68$ and hot deformation activation energy $Q=1.91 \times 10^{2} \mathrm{~kJ} / \mathrm{mol}$. We also established a constitutive equation for the magnesium alloy by using the $Z$ parameter:

$\left\{\begin{array}{l}Z=\varepsilon \exp \left(1.91 \cdot 10^{2} / R T\right) \\ \sigma=\frac{1}{0.0154} \ln \left\{\left(\frac{Z}{7.82 \cdot 10^{13}}\right)^{\frac{1}{5.68}}+\left[\left(\frac{Z}{7.82 \cdot 10^{13}}\right)^{\frac{2}{5.68}}+1\right]^{\frac{1}{2}}\right\}\end{array}\right.$

4) After extrusion deformation at $673 \mathrm{~K}$, the alloy shows mechanical properties at room and elevated temperature.

\section{Acknowledgment}

The authors are grateful for the financial support of the National Key Research and Development Program of China (No. 2016YFB0301100 and No. 2016YFB 0101600), and the Fundamental Research Funds for the Central Universities of Chongqing University (No. 106112017CDJPT280001).

\section{REFERENCES}

${ }^{1}$ Z. M. Li, A. A. Luo, Q. G. Wang, H. Zou, J. C. Dai, L. M. Peng, Fatigue characteristics of sand-cast AZ91D magnesium alloy, Journal of Magnesium and Alloys, 5 (2017) 1, 1-12, doi:10.1016/j.jma. 2017.03.001

${ }^{2}$ J. Buha, T. Ohkubo, Natural aging in $\mathrm{Mg}-\mathrm{Zn}(-\mathrm{Cu})$ alloys, Metallurgy \& Metallurgical Engineering, 39A (2008) 9, 2259-2273, doi:10.1007/s11661-008-9545-y

${ }^{3}$ S. Golmakaniyoon, R. Mahmudi, Microstructure and creep behavior of the rare-earth doped $\mathrm{Mg}-6 \mathrm{Zn}-3 \mathrm{Cu}$ cast alloy, Materials Science \& Engineering A, 528 (2011) 3, 1668-1677, doi:10.1016/j.msea. 2010.10.095

${ }^{4}$ A. A. Luo, M. O. Pekguleryuz, Cast magnesium alloys for elevated temperature applications, Journal of Materials Science, 29 (1994) 20, 5259-5271, doi:10.1007/BF01171534

${ }^{5}$ Y. B. Hu, J. Deng, C. Zhao, F. S. Pan, J. Peng, Microstructure and mechanical properties of $\mathrm{Mg}-\mathrm{Gd}-\mathrm{Zr}$ alloys with low gadolinium contents, Journal of Materials Science, 46 (2011) 17, 5838-5846, doi:10.1007/s 10853-011-5540-6
${ }^{6}$ J. Y. Li, J. X. Xie, J. B. Jin, Z. X. Wang, Microstructural evolution of AZ91 magnesium alloy during extrusion and heat treatment, Transactions of Nonferrous Metals Society of China, 22 (2012) 5, 1028-1034, doi:10.1016/S1003-6326(11)61279-X

${ }^{7}$ J. F. Wang, S. Gao, P. F. Song, X. F. Huang, Effects of phase composition on the mechanical properties and damping capacities of as-extruded $\mathrm{Mg}-\mathrm{Zn}-\mathrm{Y}-\mathrm{Zr}$ alloys, Journal of Alloys \& Compounds, 509 (2011) 34, 8567-8572, doi:10.1016/j.jallcom.2011.06.017

${ }^{8}$ Y. B. Hu, J. Deng, C. Zhao, J. F. Wang, Microstructure and mechanical properties of as-quenched Mg-Gd-Zr alloys, Transactions of Nonferrous Metals Society of China, 21 (2011) 4, 732-738, doi:10.1016/S1003-6326(11)60773-5

${ }^{9}$ F. G. Qi, D. F. Zhang, X. H. Zhang, F. S. Pan, Dynamic recrystallization during high temperature deformation of magnesium, Transactions of Nonferrous Metals Society of China, 24 (2014) 5, 1352-1364, doi:10.1016/S1003-6326(14)63199-X

${ }^{10}$ T. Al-Samman, G. Gottstein, Dynamic recrystallization during high temperature deformation of magnesium, Materials Science \& Engineering A, 490 (2008) 1-2, 411-420, doi:10.1016/j.msea. 2008.02.004

${ }^{11}$ A. Chapuis, J. H. Driver, Temperature dependency of slip and twinning in plane strain compressed magnesium single crystals, Acta Materialia, 59 (2011) 5, 1986-1994, doi:10.1016/j.actamat.2010. 11.064

${ }^{12}$ H. L. Ding, L. F. Liu, S. Kamado, W. J. Ding, Y. Kojima, Evolution of microstructure and texture of AZ91 alloy during hot compression, Materials Science \& Engineering A, 452 (2007) 24, 503-507, doi:10.1016/j.msea.2006.10.091

${ }^{13}$ S. Aliakbari. Sani, G. R. Ebrahimi, A. R. Kiani. Rashid, Hot deformation behavior and dynamic recrystallization kinetics of AZ61 and AZ61 + Sr magnesium alloys, Journal of Magnesium \& Alloys, 4 (2016) 2, 104-114, doi:10.1016/j.jma.2016.05.001

${ }^{14}$ X. L. Hou, Z. Y. Cao, X. Sun, L. D. Wang, L. M. Wang, Twinning and dynamic precipitation upon hot compression of a Mg-Gd-Y$\mathrm{Nd}-\mathrm{Zr}$ alloy, Journal of Alloys \& Compounds, 525 (2012) 10, 103-109, doi:10.1016/j.jallcom.2012.02.081

${ }^{15}$ T. Zhang, J. Jun, J. X. Sang, Y. Li, P. P. Pei, Effects of sn addition on the microstructures and mechanical properties of $\mathrm{Mg}-6 \mathrm{Zn}-3 \mathrm{Cu}-\mathrm{X} \mathrm{Sn}$ magnesium alloys, Metallurgical \& Materials Transactions A, 46 (2015) 8, 1-12, doi:10.1007/s11661-015-2951-z

${ }^{16}$ J. H. Jun, J. M. Kim, B. K. Park, K. T. Kim, W. J. Jung, Effects of rare earth elements on microstructure and high temperature mechanical properties of ZC63 alloy, Journal of Materials Science, 40 (2005) 9-10, 2659-2661, doi:10.1007/s10853-005-2099-0

${ }^{17}$ L. Gao, H. Yan, J. Luo, A. A. Luo, R. S. Chen, Microstructure and mechanical properties of a high ductility $\mathrm{Mg}-\mathrm{Zn}-\mathrm{Mn}-\mathrm{Ce}$ magnesium alloy, Journal of Magnesium \& Alloys, 1 (2013) 4, 283-291, doi:10.1016/j.jma.2013.11.005

${ }^{18}$ S. H. Wei, Y. G. Chen, Y. B. Tang, X. P. Zhang, M. Liu, S. F. Xiao, Y. H. Zhao, Compressive creep behavior of Mg-Sn-La alloys, Materials Science \& Engineering A, 508 (2009) 1-2, 59-63, doi:10.1016/j.msea.2008.12.049

${ }^{19} \mathrm{~S}$. Golmakaniyoon, R. Mahmudi, Comparison of the effects of Laand Ce-rich rare earth additions on the microstructure, creep resistance, and high-temperature mechanical properties of $\mathrm{Mg}-6 \mathrm{Zn}-3 \mathrm{Cu}$ cast alloy, Materials Science \& Engineering A, 528 (2011) 15, 5228-5233, doi:10.1016/j.msea.2011.03.083

${ }^{20}$ P. Liu, H. T. Jiang, Z. X. Cai, Q. Kang, Y. Zhang, The effect of y, ce and gd on texture, recrystallization and mechanical property of mg-zn alloys, Journal of Magnesium \& Alloys, 4 (2016) 3, 188-196, doi:10.1016/j.jma.2016.07.001

${ }^{21}$ J. Wang, X. J. Zhang, X. Lu, Y. S. Yang, Z. H. Wang, Microstructure, texture and mechanical properties of hot-rolled mg-4al-2sn$0.5 \mathrm{y}-0.4 \mathrm{nd}$ alloy, Journal of Magnesium \& Alloys, 4 (2016) 3, 207-213, doi:10.1016/j.jma.2016.07.004

${ }^{22}$ X. Liu, Z. Q. Zhang, Q. C. Le, L. Bao, Effects of nd/gd value on the microstructures and mechanical properties of $\mathrm{Mg}-\mathrm{Gd}-\mathrm{Y}-\mathrm{Nd}-\mathrm{Zr}$ alloys, Journal of Magnesium \& Alloys,4 (2016) 3, 214-219, doi:10.1016/j.jma.2016.06.002 
${ }^{23}$ F. Abbassi, M. Srinivasan, C. Loganathan, R. Narayanasamy, M. Gupta, Experimental and numerical analyses of magnesium alloy hot workability, Journal of Magnesium \& Alloys, 4 (2016) 4, 295-301, doi:10.1016/j.jma.2016.10.004

${ }^{24}$ S. W. Xu, S. Kamado ,T. Honma, Recrystallization mechanism and the relationship between grain size and Zener-Hollomon parameter of $\mathrm{Mg}-\mathrm{Al}-\mathrm{Zn}-\mathrm{Ca}$ alloys during hot compression, Scripta Materialia, 63 (2010) 3, 293-296, doi:10.1016/j.scriptamat.2010.04.012

${ }^{25}$ S. W. Xu, N. Matsumoto, S. Kamado, T. Honma, Y. Kojima, Dynamic microstructural changes in $\mathrm{Mg}-9 \mathrm{Al}-1 \mathrm{Zn}$ alloy during hot compression, Scripta Materialia, 61 (2009) 3, 249-252, doi:10.1016/ j.scriptamat.2009.03.051

${ }^{26}$ G. R. Ebrahimi, A. R. Maldar, R. Ebrahimi, A. Davoodi, Effect of thermomechanical parameters on dynamically recrystallized grain size of AZ91 magnesium alloy. Journal of Alloys and Compounds, 509 (2011) 6, 2703-2708. doi:10.1016/j.jallcom.2010.11.134

${ }^{27}$ Y. J. Qin, Q. L. Pan, Y. B. He, W. B. He, X. Y. Liu, X. Pan, Modeling of flow stress for magnesium alloy during hot deformation, Materials Science \& Engineering A, 527 (2010) 10-11, 2790-2797, doi:10.1016/j.msea.2010.01.035

${ }^{28}$ O. Grydin, M. Stolbchenko, F. Nurnberger, M. Schaper, Influence of Hot Deformation on Mechanical Properties and Microstructure of a Twin-Roll Cast Aluminium Alloy EN AW-6082, Journal of Materials Engineering \& Performance, 23 (2014) 3, 937-943, doi:10.1007/ s11665-013-0816-4
${ }^{29}$ X. C. Li, Y. L. Lu, J. T. Wang, L. Dou, Microstructural Evolution of Magnesium Alloy during Hot Compression, Applied Mechanics \& Materials, 446-447 (2013), 158-163, doi:10.4028/www.scientific.net/AMM.446-447.158

${ }^{30}$ S. W. Xu, S. Kamado, N. Matsumoto, T. Honma, Y. Kojima, Recrystallization mechanism of as-cast AZ91 magnesium alloy during hot compressive deformation, Materials Science \& Engineering A, 725 (2009) 1-2, 52-60, doi:10.1016/j.msea.2009.08.062

${ }^{31}$ S. E. Ion, F. J. Humphreys, S. H. White, Dynamic recrystallisation and the development of microstructure during the high temperature deformation of magnesium, Acta Metallurgica, 30 (1982) 10, 1909-1919, doi:10.1016/0001-6160(82)90031-1

${ }^{32}$ Y. Lou, L. X. Li, N. Luan, Flow Stress Correction of AZ80 Magnesium Alloy for Deformation Heating at High Strain Rates during Hot Compression, Advanced Materials Research, 129-131 (2010), 1326-1330, doi:10.4028/www.scientific.net/AMR.129-131.1326

${ }^{33}$ H. Y. Wu, J. C. Yang, J. H. Liao, F. J. Zhu, Dynamic behavior of extruded AZ61 Mg alloy during hot compression, Materials Science \& Engineering A, 535 (2012), 68-75, doi:10.1016/j.msea.2011. 12.043

${ }^{34}$ Y. J. Qin, Q. L. Pan, Y. B. He, W. B. Li, X. Y. Liu, X. Pan, Artificial Neural Network Modeling to Evaluate and Predict the Deformation Behavior of ZK60 Magnesium Alloy During Hot Compression, Materials \& Manufacturing Processes, 25 (2010) 7, 539-545, doi:10.1080/10426910903124894 